\title{
Nickel-(Bi,Ag) sulphide mineralization from NYF Vepice pegmatite, Milevsko pluton, southern Bohemia (Czech Republic) - a reflection of the parental granite chemistry
}

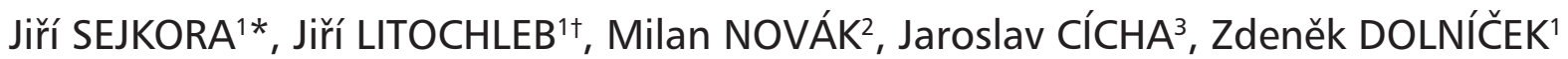 \\ ${ }^{1}$ Department of Mineralogy and Petrology, National museum, Cirkusová 1740, CZ-190 00, Prague 9, Czech Republic; jiri.sejkora@nm.cz \\ 2 Department of Geological Sciences, Masaryk University, Kotlářská 2, 61137 Brno, Czech Republic \\ ${ }^{3}$ Prácheň museum, Velké náměstí 114, 39724 Písek, Czech Republic \\ * Corresponding author \\ †Deceased
}

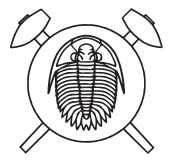

Unusual high- to low-T sulphide mineralization with Ni-(Bi, Ag) phases was examined at the NYF intragranitic pegmatite No. III from Vepice near Kovářov enclosed in the Milevsko Pluton, Moldanubian Zone, Southern Bohemia. Zoned pegmatite dike, up to $30 \mathrm{~cm}$ thick, has transitional contact with host durbachite and its internal structure includes transitional unit, border granitic unit, graphic unit, blocky unit (Kfs+Qz), quartz core and small miarolitic pocket. Sulphide mineralization locally associated with calcite and fluorite is represented by common pyrite with minor galena, accessory chalcopyrite, sphalerite, marcasite, native $\mathrm{Bi}$ and $\mathrm{Ni}-(\mathrm{Bi}, \mathrm{Ag})$ minerals - argentopentlandite, parkerite and pentlandite. It is developed in small miarolitic pockets and on pegmatite fractures cutting all pegmatite units. Irregular anhedral grains and aggregates of argentopentlandite, $<200 \mu \mathrm{m}$ in size, associated with chalcopyrite, have empirical formula $\mathrm{Ag}_{0.97}\left(\mathrm{Fe}_{4.88} \mathrm{Ni}_{3.10} \mathrm{Cu}_{0.04} \mathrm{Co}_{0.01}\right)_{\Sigma 8.03}\left(\mathrm{~S}_{7.96} \mathrm{As}_{0.03}\right)_{\Sigma 7.99}$. Zoned irregular aggregates of parkerite, 20-30 $\mu \mathrm{m}$ in size, are typically associated with pentlandite, or overgrow galena and yield empirical formula $\left(\mathrm{Ni}_{3.02} \mathrm{Fe}_{0.02} \mathrm{Co}_{0.01}\right)_{\Sigma 3.06}\left(\mathrm{Bi}_{1.73} \mathrm{Sb}_{0.05} \mathrm{As}_{0.04}\right)_{\Sigma 1.92}$ $\mathrm{S}_{2.02}$. Pentlandite is present in two morphological forms: rare lenticular to isometric anhedral grains, $\leq \sim 200 \mu \mathrm{m}$ in size, and numerous small tabular crystals, $\leq 20 \mu \mathrm{m}$ in length, in subparallel arrangement rimming aggregates of other sulphides. Empirical formula is $\left(\mathrm{Ni}_{4.57} \mathrm{Fe}_{4.14} \mathrm{Co}_{0.25}\right)_{\Sigma 8.96}\left(\mathrm{~S}_{8.01} \mathrm{As}_{0.02}\right)_{\Sigma 8.03}$. Evaluation of relative chronology of the sulphide minerals is complicated mainly due to complex textural relations. Pyrite + marcasite are likely pseudomorphs after pyrrhotite as the earliest phase whereas pentlandite and native $\mathrm{Bi}$ are among the latest. Early sulphides (pyrrhotite, chalcopyrite, sphalerite, argentopentlandite) crystallized at $\mathrm{T}<\sim 550-400^{\circ} \mathrm{C}$, whereas pyrite, marcasite, galena, parkerite, and native $\mathrm{Bi}$ at $\mathrm{T}<240^{\circ} \mathrm{C}$. Cooling of the system below $\mathrm{T} \sim 200^{\circ} \mathrm{C}$ appeared soon after transformation of pyrrhotite to pyrite + marcasite aggregates. Sulphides manifest that concentrations of $\mathrm{Ni}$ in residual pegmatite melt and exsolved fluids were high enough to facilitate saturation of Ni-sulphides. Very high $\mathrm{Ni} / \mathrm{Co}$ ratio in sulphides reflects a much lower concentration of cobalt in durbachite. The examined Ni-(Bi, $\mathrm{Ag})$ sulphides manifest that high concentrations of highly compatible Ni in parental granite may be reflected in accessory minerals from its pegmatite.

Keywords: argentopentlandite, parkerite, pentlandite, EPMA data, NYF pegmatite, Czech Republic

Received: 22 March 2020; accepted: 25 August 2020; handling editor: J. Zachariáš

\section{Introduction}

Sulphides/arsenides and sulphosalts are common to rare accessory minerals in granitic pegmatites. They contain a broad spectrum of metal elements and relevant minerals including (i) common Fe-dominant phases (e.g., pyrite, arsenopyrite, löllingite, pyrrhotite, marcasite), (ii) molybdenite, (iii) Bi-rich phases (e.g., bismuthinite, cuprobismutite, cosalite, gustavite, gladite, pekoite, joséite), and (iv) base metal - $\mathrm{Cu}, \mathrm{Pb}, \mathrm{Zn}, \mathrm{Cd}, \mathrm{Sb}, \mathrm{Ag}$-bearing phases (e.g., chalcopyrite, galena, sphalerite, greenockite, hawleyite, tetrahedrite-group, bournonite, pyrargyrite, miargyrite). Except for Fe, sulphides are commonly the only carriers of these elements in granitic pegmatites with some exceptions such as native metals (bismuth, arsenic) or oxides (gahnite, stibiotantalite, bismite, bismutotantalite, pyrochlore-group minerals). However, trace to minor concentrations of these elements may be hidden in some $\mathrm{Fe}, \mathrm{Mn}, \mathrm{Mg}$-rich minerals such as biotite and tourmaline (e.g., Soares et al. 2008; Novák et al. 2011; Johan et al. 2012; Čopjaková et al. 2013, 2015). In sulphides and sulphosalts some elements are present which are carried in granitic pegmatites mostly in oxides such as Sn (e.g., stannite, kesterite, černýite, herzenbergite; Kissin et al. 1978; Smeds 1993; Losos et al. 1998; Černý et al. 2001; Škoda and Čopjaková 2005) and W (tungstenite; Breiter et al. 2010). Rather exceptionally, pegmatite-hosted sulphides may contain some specific elements such as Te (Fuksová et al. 2011; Márquez-Zavalía et al. 2012) but sulphides with a substantial amount of $\mathrm{Ni}$, a highly 
compatible element typical for ultrabasic rocks, have not been known from granitic pegmatites.

Sulphides/arsenides and sulphosalts occur in various types and subtypes of granitic pegmatites from primitive to highly fractionated, both LCT (Lithium-Cesium-Tantalum) and NYF (Niobium-Yttrium-Fluorine) families; however, they were only sporadically studied in detail (e.g., Oen and Kieft 1976; Černý and Harris 1978; Losos et al. 1998; Černý et al. 2001; Ciobanu and Cook 2002; Márquez-Zavalía et al. 2012; Pieczka and Gołębiowska 2012). Also, our knowledge about their position in pegmatite evolution is rather poor; usually, they are hydrothermal and crystallized at low $\mathrm{T}<$ $\sim 200^{\circ} \mathrm{C}$ (Černý and Harris 1978; Márquez-Zavalía et al. 2012) but high-T assemblages which crystallized at $\mathrm{T} \sim 500-400^{\circ} \mathrm{C}$ (e.g., Oen and Kieft 1976; Losos et al. 1998; Černý et al. 2001) also were described. Absence of systematic studies does not enable any generalization about occurrences of sulphides in granitic pegmatites in respect to affiliation to pegmatite families and degree of fractionation, although rich sulphide assemblages are mostly known from highly fractionated complex Li-pegmatites (e.g., Černý and Harris 1978; Černý et al. 2001; Márquez-Zavalía et al. 2012).

We studied unusual Ni-(Bi, Ag) sulphide mineralization occurring in intraplutonic NYF pegmatite at Vepice near Kovářov derived from the Milevsko Pluton. The parental granite is ultrapotassic magnesium-rich $I$-type melagranite related to the Variscan orogeny (Žák et al. 2005). We discuss the chemical composition of sulphides, their textural relations, conditions of origin as well as the origin of $\mathrm{Ni}$ and other metals in the pegmatite.

\section{Geological setting and internal structure of NYF pegmatites from durbachite plutons}

The pegmatite with sulphide mineralization is enclosed in ultrapotassic rocks of the Milevsko Pluton. Ultrapotassic, magnesium-rich, biotite-amphibole to biotite-pyroxene quartz syenitic to melagranitic rocks, durbachites, form several large, mostly flat intrusions in the Moldanubian Zone (Žák et al. 2005; Leichmann et al. 2017). These syn-exhumation tabular bodies are interpreted as a product of mixing between enriched mantle magma and a crustal melt (e.g., Holub 1997; Janoušek and Holub 2007), and belong to shoshonitic association of the ultrapotassic plutonic rocks $\left(\mathrm{MgO}>3\right.$ wt. $\left.\%, \mathrm{~K}_{2} \mathrm{O} / \mathrm{Na}_{2} \mathrm{O}>2\right)$. They were classified by Finger et al. (1997) as high-K, I-type granitoids characterized by metaluminous signature and high content of $\mathrm{K}_{2} \mathrm{O}(5.2-6.8$ wt. \%), $\mathrm{MgO}$ (3.310.4 wt. \%), $\mathrm{P}_{2} \mathrm{O}_{5}(0.47-0.98$ wt. \%), $\mathrm{Rb}(330-410$ ppm),
$\mathrm{Ba}(1100-2470 \mathrm{ppm}), \mathrm{U}(6.7-26.2 \mathrm{ppm})$, Th (28.2-47.7 ppm), Cr (270-650 ppm), Ni (59-235), Co (14-28), $\mathrm{W}$ (7-8), Sc (12-27), Cs (20-40 ppm), and high ratio $\mathrm{K} / \mathrm{Rb}=133-171$ (Holub 1997; Janoušek et al. 2020). The intrusions followed shortly after exhumation of the high-grade Gföhl unit into mid-crustal levels at 343-335 Ma (e.g., Janoušek et al. 2019 and references therein).

Intragranitic pegmatites of NYF family occur in some Variscan durbachite plutons - mainly in the Třebíc Pluton (e.g., Škoda et al. 2006; Škoda and Novák 2007; Novák and Filip 2010; Novák et al. 2011; Zachař and Novák 2013; Zachař et al. 2020), in the Milevsko Pluton (Škoda et al. 2004; Novák 2005) and the Mehelník Pluton near Písek (Novák et al. 2017). The pegmatites in the Třebíc Pluton were divided based on their mineral assemblages, degree of geochemical fractionation and internal structure onto (i) geochemically primitive allanite-type pegmatites, and (ii) more evolved euxenite-type pegmatites (Novák et al. 1999, 2012; Škoda et al. 2006; Škoda and Novák 2007; Zachař and Novák 2013). They relate to the RELREE subclass, rare-element class of the NYF family (Černý and Ercit 2005); however, they are F-poor and do not entirely fit the definition of NYF family (Simmons and Webber 2008). Martin and De Vito (2005) considered the pegmatites of Třebíc Pluton to be NYF-related and a specific type of pegmatite derived from ultrapotassic orogenic pluton belonging to a shoshonitic association (see Žák et al. 2005). Most NYF intragranitic pegmatites in durbachite plutons contain along with feldspars and quartz minor to rare phlogopite, accessory black tourmaline (Ca, Ti-rich Al-poor schorl-dravite; Novák et al. 2011; Čopjaková et al. 2013), and primary muscovite is absent. Common to rare accessory minerals include titanite, allanite-(Ce), Y, REE, $\mathrm{Nb}, \mathrm{Ta}$, Ti-oxide minerals, ilmenite, niobian rutile, zircon, pyrite, arsenopyrite, galena and several primary Be-minerals - beryl, phenakite, helvite-danalite and milarite (Novák and Čech 1996; Škoda et al. 2006; Škoda and Novák 2007; Novák and Filip 2010; Novák et al. 2017; Zachař et al. 2020).

\section{Analytical techniques}

Polished sections of the studied samples from Vepice were prepared for optical investigation and chemical analysis using standard diamond polishing techniques. Optical properties of opaque minerals in reflected light were observed with a Nikon Eclipse ME600 microscope.

Quantitative chemical composition of minerals was determined with a Cameca SX100 electron microanalyser (GÚDŠ, Bratislava) operated at the following conditions: WD analysis, $25 \mathrm{kV}, 20 \mathrm{nA}$, electron beam diameter less than $1 \mu \mathrm{m}$. The following standards and lines were used: 
$\mathrm{Ag}\left(\mathrm{Ag} L_{\alpha}\right), \mathrm{Bi}\left(\mathrm{Bi} L_{\alpha}\right), \mathrm{Cd}\left(\mathrm{Cd} L_{\alpha}\right)$, chalcopyrite $\left(\mathrm{S} K_{\alpha}\right.$, $\left.\mathrm{Cu} K_{\alpha}, \mathrm{Fe} K_{\alpha}\right), \mathrm{Co}\left(\mathrm{Co} K_{\alpha}\right), \mathrm{FeAsS}\left(\operatorname{As} K_{\beta}\right), \operatorname{HgS}\left(\operatorname{Hg} L_{\alpha}\right)$, $\mathrm{NaCl}\left(\mathrm{Cl} K_{\alpha}\right), \mathrm{Ni}\left(\mathrm{Ni}_{\alpha}\right), \mathrm{Bi}_{2} \mathrm{Se}_{3}\left(\mathrm{Se}_{\beta}\right), \mathrm{PbS}\left(\mathrm{Pb} M_{\alpha}\right), \mathrm{Sb}_{2} \mathrm{~S}_{3}$ $\left(\mathrm{Sb} L_{\beta}\right), \mathrm{SnO}_{2}\left(\mathrm{Sn} L_{\beta}\right)$ and $\mathrm{ZnS}\left(\mathrm{Zn} K_{\alpha}\right)$. The abundances of the above elements, if not included in tables of analytical data, were measured, but the values were below the detection limit (0.01-0.03 wt. \% for individual elements). Measured data were corrected using PAP software (Pouchou and Pichoir 1985).

\section{Granitic pegmatites from the Vepice locality}

At Vepice near Kovářov, southern Bohemia, host durbachite is porphyric amphibole-biotite melagranite of the Milevsko Pluton representing the light variety of durbachitic series. Several pegmatite bodies were discovered and examined in the quarry located $\sim 0.3 \mathrm{~km}$ $\mathrm{S}$ of Vepice. The pegmatite No. I forms a large nest, $2.5-3.5 \mathrm{~m}$ in size, with a central pocket, $1.5 \times 1.3 \times 0.8 \mathrm{~m}$

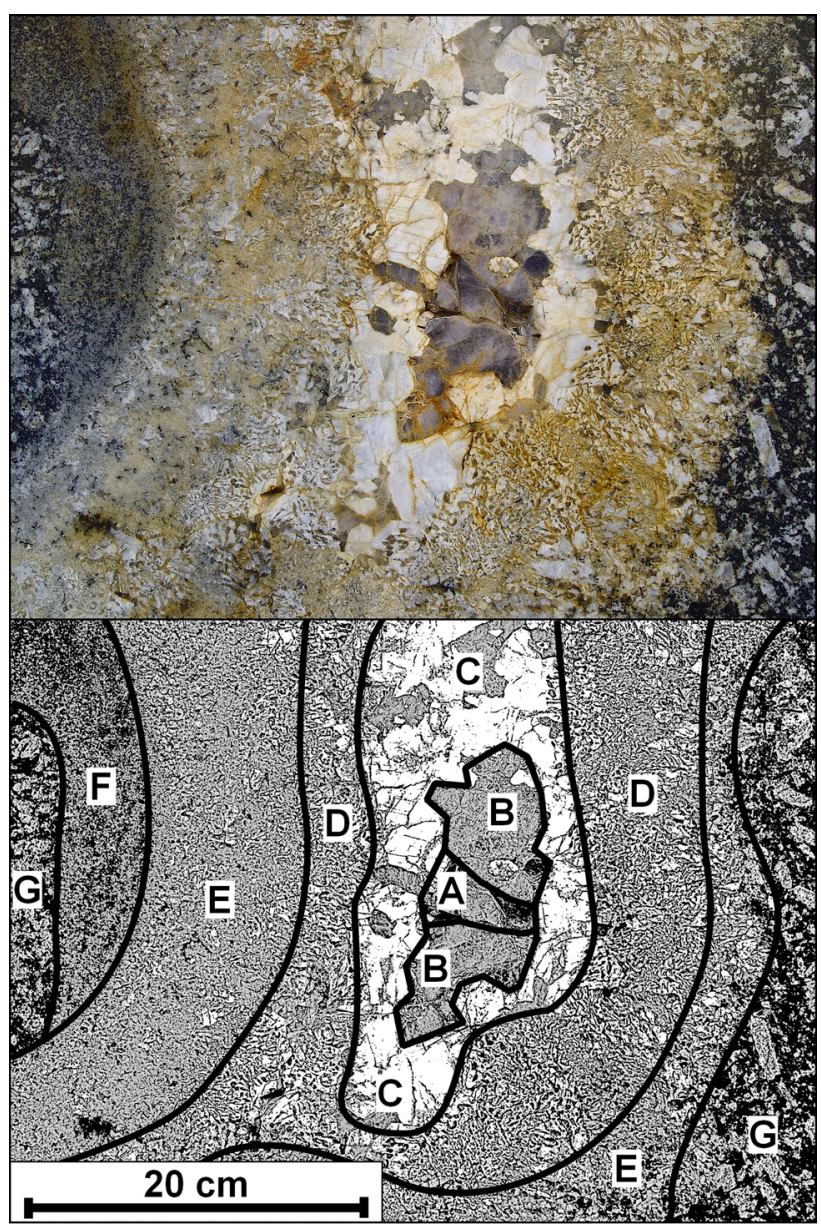

Fig. 1 Cross-section of the pegmatite No. III. A - miarolitic pocket, $\mathrm{B}$ - quartz core, $\mathrm{C}$ - blocky unit (Kfs), D - graphic unit, $\mathrm{E}$ - border granitic unit, $\mathrm{F}$ - transitional unit, $\mathrm{G}$ - melagranite. Photo J. Cícha. across, studied in detail by Škoda et al. (2004). The zoned body is built from melagranite inwards of amphibole-rich zone in melagranite, granitic unit $(\mathrm{Plg}+\mathrm{Kfs}+\mathrm{Qz}+\mathrm{Bi})$, graphic unit (Kfs+Qz+Bi), blocky unit (Kfs), albite unit $(\mathrm{Ab}+\mathrm{Qz})$, quartz core, and central miarolitic pocket $(\mathrm{Qz}+\mathrm{Ab}+\mathrm{Kfs})$. It contains numerous accessory minerals: titanite, ilmenite, $\mathrm{Nb}, \mathrm{Ta}$, Ti-oxides (e.g., samarskite, pyrochlore, columbite, fersmite), zircon, scheelite, and uraninite. Sulphide mineralization with dominant pyrite and minor galena is developed in blocky K-feldspar and central pocket locally in well-developed crystals, up to 3 $\mathrm{mm}$ in diameter. Rare molybdenite occurs with $\mathrm{Y}, R E E$, $\mathrm{Nb}, \mathrm{Ta}$, Ti-oxide minerals. A small nest of the pegmatite No. II, $\sim 0.7-0.5 \mathrm{~m}$ in size, occurs $\sim 20 \mathrm{~m} \mathrm{~N}$ of the large pegmatite No. I. It is similar in its internal structure and common titanite and rare $\mathrm{Y}, R E E, \mathrm{Nb}, \mathrm{Ta}, \mathrm{Ti}$-oxide minerals. The mineral assemblage is simpler except for sulphidic mineralization in masses, up to several $\mathrm{dm}^{3}$ in size. It is represented by dominant pyrite and minor to accessory galena, sphalerite, chalcopyrite, bismuthinite and native Bi. Sulphides are also developed on fractures cutting blocky unit, quartz core and in central pocket. The pegmatite No. III, where $\mathrm{Ni}-(\mathrm{Bi}, \mathrm{Ag})$ mineralization has been examined in detail in this study, is located $\sim 30 \mathrm{~m}$ to the West from the pegmatite No. I and differs both in shape and size. It is built of a system of elongated, subparallel dikes, $\sim 5$ to $30 \mathrm{~cm}$ thick and several $\mathrm{m}$ long. In more evolved portions, the dikes have a similar internal structure and textural-paragenetic units as the pegmatites Nos. I and II, including small quartz core and miarolitic pockets (Fig. 1). Along with quartz, feldspars and phlogopite, coarse-grained aggregates of calcite, up to $2 \mathrm{~cm}$ in size, euhedral titanite and rare tourmaline, were found in the blocky unit. Sulphide mineralization represented by common pyrite with minor galena and $\mathrm{Ni}-(\mathrm{Bi}, \mathrm{Ag})$ minerals along with several accessory sulphides occurs mainly in small miarolitic pockets in quartz core and on pegmatite fractures cutting all pegmatite units.

\section{Results}

\subsection{Paragenetic position, textural relations and chemical composition of common sulphides}

Studied samples of sulphides were collected in 2007 at the pegmatite No. III as aggregates of sulphides, about $1 \mathrm{~cm}$ in diameter, with dominant pyrite and galena and common fluorite and calcite. Chalcopyrite forms irregular aggregates, up to $5 \mathrm{~mm}$ in size, intimately associated especially with argentopentlandite (Fig. 2a). Exceptionally, veinlets of Ag-rich chalcopyrite with $\leq 0.04$ apfu Ag (Fig. 2b, Tab. 1) were found. Such contents 

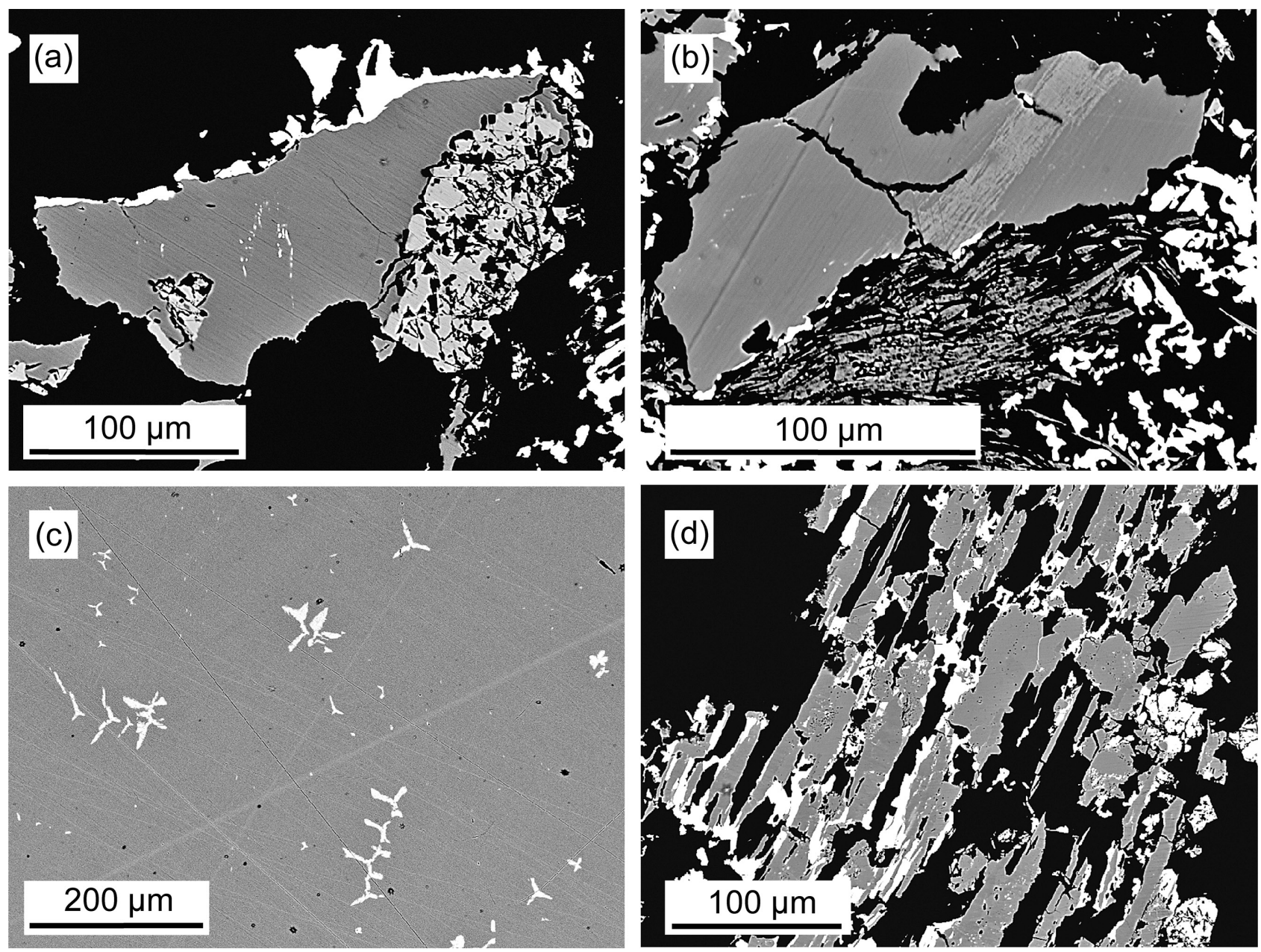

Fig. 2 BSE photographs. a - chalcopyrite aggregate (dark grey) associated with argentopentlandite (light grey) and galena (white); b - chalcopyrite aggregates (dark grey) with Ag-rich veinlets with subparallel arranged tabular pentlandite crystals (grey) and galena (white); $\mathbf{c}-$ chalcopyrite (grey) with ternate sphalerite stars (white); d - pyrite-marcasite aggregates (grey) rimmed by galena (white).

are exceptional and about one order higher than the published data (Harris et al. 1984; Losos et al. 1998). Dominant chalcopyrite contains an only trace amount of $\mathrm{Ag}$ (Tab. 1) but elevated $\mathrm{Bi}(\leq 0.002$ apfu). Chalcopyrite often contains small ternate sphalerite stars, up to $40 \mu \mathrm{m}$ in size (Fig. 2c). A common polysynthetic twinning of chalcopyrite is observed in reflected light (Fig. 3). Subhedral grains of galena, up to $5 \mathrm{~mm}$ in size, con- tain elevated contents of $\mathrm{Ag}(\leq 0.01 a p f u)$ and $\mathrm{Bi}$ (up to 0.02 apfu) (Tab. 1); low concentrations of $\mathrm{Cl}$ $(\leq 0.01$ apfu $)$ are remarkable. Pyrite and marcasite form isolated fine-grained, porous aggregates up to $5 \mathrm{~mm}$ in diameter, rimmed by chalcopyrite, galena (Fig. 2d) and pentlandite. Pyrite is present usually in euhedral isometric and isotropic crystals, up to $50 \mu \mathrm{m}$ in size, rimmed by elongated subparallel individuals of optically anisotropic marcasite. In BSE images, pyrite is somewhat lighter than marcasite because of its elevated contents of $\mathrm{Ni}$ (Tab. 1) reaching up to 0.05 apfu as well as minor Co $(\leq 0.01 \mathrm{apfu})$. The porosity of pyrite-marcasite aggregates,

Fig. 3 Polysynthetic twinning of chalcopyrite containing small stars of sphalerite; polished section, reflected light, field of view $1.5 \mathrm{~mm}$; $\mathbf{a}$ - plane-polarised light; $\mathbf{b}$ - partly crossed polars. 
Tab. 1 Representative chemical analyses of common sulphide minerals (wt. \%)

\begin{tabular}{|c|c|c|c|c|c|c|c|c|c|c|c|c|c|c|c|c|}
\hline \multirow[b]{2}{*}{$\mathrm{Ag}$} & \multicolumn{3}{|c|}{ bismuth } & \multicolumn{4}{|c|}{ chalcopyrite } & \multicolumn{3}{|c|}{ galena } & \multicolumn{3}{|c|}{ pyrite } & \multicolumn{3}{|c|}{ sphalerite } \\
\hline & 0.00 & 0.00 & 0.00 & 2.11 & 2.51 & 0.03 & 0.02 & 0.44 & 0.49 & 0.44 & 0.00 & 0.00 & 0.00 & 0.00 & 0.00 & 0.00 \\
\hline $\mathrm{Fe}$ & 0.00 & 0.00 & 0.00 & 29.44 & 29.12 & 30.18 & 30.35 & 0.00 & 0.00 & 0.00 & 44.58 & 44.68 & 44.72 & 10.39 & 8.50 & 9.13 \\
\hline $\mathrm{Pb}$ & 2.53 & 1.77 & 1.88 & 0.10 & 0.08 & 0.10 & 0.00 & 84.73 & 84.76 & 84.92 & 0.08 & 0.14 & 0.07 & 0.00 & 0.00 & 0.00 \\
\hline $\mathrm{Cd}$ & 0.16 & 0.11 & & 0.00 & 0.00 & 0.00 & 0.00 & 0.00 & 0.00 & 0.00 & 0.00 & 0.00 & 0.00 & 1.19 & 0.55 & 0.90 \\
\hline In & 0.00 & 0.00 & 0.00 & 0.00 & 0.00 & 0.00 & 0.00 & 0.00 & 0.00 & 0.00 & 0.00 & 0.00 & 0.00 & 0.10 & 0.08 & 0.10 \\
\hline $\mathrm{Ni}$ & 0.00 & 0.00 & 0.00 & 0.07 & 0.09 & 0.05 & 0.00 & 0.00 & & & 2.43 & 1.81 & 2.26 & 0.00 & 0.00 & 0.00 \\
\hline $\mathrm{Mn}$ & 0.00 & 0.00 & 0.00 & 0.00 & 0.00 & 0.00 & 0.00 & 0.00 & 0.00 & 0.00 & 0.00 & 0.00 & 0.00 & 0.06 & 0.03 & 0.00 \\
\hline $\mathrm{Zn}$ & 0.00 & 0.00 & & 0.00 & 0.00 & 0.00 & & & & & 0.00 & 0.00 & & & 56.02 & 56.94 \\
\hline $\mathrm{Cu}$ & 0.00 & 0.00 & 0.00 & 33.31 & 33.57 & 34.21 & 34.62 & 0.00 & 0.00 & 0.00 & 0.00 & 0.00 & 0.00 & 0.00 & 0.00 & 0.00 \\
\hline $\mathrm{Sb}$ & 0.41 & 0.00 & & & & & & & & & & & & & & 0.09 \\
\hline $\mathrm{Bi}$ & 94.96 & 96.43 & 98.12 & 0.04 & 0.13 & 0.20 & & & 1.40 & & 0.00 & 0.00 & 0.00 & 0.00 & 0.27 & 0.07 \\
\hline As & 1.49 & 1.46 & 0.00 & 0.67 & 0.31 & 0.49 & 0.21 & 0.00 & 0.00 & 0.00 & 0.00 & 0.00 & 0.00 & 0.00 & 0.00 & 0.00 \\
\hline $\mathrm{Cl}$ & 0.00 & 0.00 & & & 0.00 & & & & & & 0.00 & 0.00 & 0.00 & 0.00 & 0.00 & 0.00 \\
\hline total & 9.53 & 99.78 & 0.12 & & 99.91 & 100.10 & & & & & & & & & 98.90 & 100.78 \\
\hline $\mathrm{Ag}$ & 0.000 & 0.000 & & & 0.043 & & & & & & & & & & & 0.000 \\
\hline $\mathrm{Fe}$ & 0.000 & 0.000 & 0.000 & 0.979 & 0.973 & 0.994 & 0.998 & 0.000 & 0.000 & 0.000 & 0.952 & 0.964 & 0.958 & 0.178 & 0.148 & 0.156 \\
\hline $\mathrm{Pb}$ & 0.025 & 0.017 & & & & & & & & & & & & & & 0.000 \\
\hline $\mathrm{Cd}$ & 0.003 & 0.002 & & & & & & & & & & & & & & \\
\hline In & 0.000 & 0.000 & 0.000 & 0.000 & 0.000 & 0.000 & 0.000 & & 0.000 & & & 0.000 & 0.000 & 0.001 & 0.001 & 0.001 \\
\hline $\mathrm{Ni}$ & 0.000 & 0.000 & & & 0.003 & & & & & & & & & & & 0.000 \\
\hline $\mathrm{Co}$ & 0.000 & 0.000 & 0.000 & 0.002 & 0.000 & 0.001 & 0.000 & 0.000 & 0.000 & 0.000 & 0.002 & 0.005 & 0.001 & 0.000 & 0.000 & 0.000 \\
\hline $\mathrm{Mn}$ & 0.000 & 0.000 & & 0.000 & 0.000 & 0.000 & & & & & & 0.000 & & 0.001 & 0.001 & 0.000 \\
\hline $\mathrm{Zn}$ & 0.000 & 0.000 & & & 0.000 & & & & & & & & & & & \\
\hline $\mathrm{Cu}$ & 0.000 & 0.000 & 0.000 & 0.974 & 0.986 & 0.990 & 1.000 & 0.000 & 0.000 & 0.000 & 0.000 & 0.000 & 0.000 & 0.000 & 0.000 & 0.000 \\
\hline $\mathrm{Sb}$ & 0.007 & 0.000 & 0.000 & 0.000 & 0.000 & 0.000 & 0.000 & 0.003 & & & & 0.000 & 0.000 & 0.000 & 0.000 & 0.001 \\
\hline $\mathrm{S}$ & 0.000 & 0.000 & 0.000 & 1.989 & 1.985 & 1.997 & 1.994 & 1.003 & 1.009 & 1.011 & 1.996 & 1.993 & 1.994 & 1.006 & 1.012 & 1.001 \\
\hline $\mathrm{Cl}$ & 0.000 & 0.000 & 0.000 & 0.000 & 0.000 & 0.000 & 0.000 & 0.006 & 0.005 & 0.004 & 0.000 & 0.000 & 0.000 & 0.000 & 0.000 & 0.000 \\
\hline basis & 1 & 1 & 1 & 4 & 4 & 4 & 4 & 2 & 2 & 2 & 3 & 3 & 3 & 2 & 2 & 2 \\
\hline
\end{tabular}

Coefficients of empirical formula were calculated on the basis (apfu) listed in the last row of the table.

reaching $\sim 30$ vol. $\%$, is filled by gangue minerals, which are partly replaced by younger sulphides (chalcopyrite, argentopentlandite, galena) in marginal parts of aggregates. Exceptionally, a veinlet of pyrite-marcasite cutting chalcopyrite but not continuing into gangue was observed. Rare sphalerite was found as star-shaped aggregates in chalcopyrite (Fig. 2c) and irregular to isolated aggregates, $\leq 300 \mu \mathrm{m}$ in diameter, associated with chalcopyrite, galena, pentlandite and argentopentlandite. Larger sphalerite grains usually contain small spherical randomly distributed blebs of chalcopyrite, representing typical "chalcopyrite disease". Sphalerite contains moderate contents of $\mathrm{Fe}(0.15-0.18 \mathrm{apfu})$ and low $\mathrm{Cd}(\leq 0.01$ apfu) (Tab. 1). Bismuth forms small isometric grains $(\leq 30 \mu \mathrm{m})$ or thin veinlets in galena. Low concentrations of $\mathrm{Pb} \leq 0.02$ apfu (Tab. 1) are typical as well as low As $\leq 0.04$ apfu and exceptionally $\mathrm{Sb} \leq 0.01$ apfu. Sharply contoured small domains overfilled by minute inclusions of native bismuth were observed exceptionally in some galena aggregates.

\subsection{Paragenetic position, textural relations and chemical composition of $\mathrm{Ni}-(\mathrm{Bi}, \mathrm{Ag})$ sulphides}

The examined Ni-(Bi, Ag) sulphides occur only in microscopic scale as irregular aggregates in assemblage with major and minor sulphides.

Argentopentlandite forms irregular anhedral grains and aggregates, $<200 \mu \mathrm{m}$ in size, overgrowing and enclosed by aggregates of chalcopyrite (Fig. 2a, 4a). Based on the refinement of the crystal structure (Hall and Stewart 1973), chemical analyses from numerous localities (Morales-Ruano and Hach-Alí 1996) and phase relations in the system Ag-Fe-Ni-S (Mandziuk and Scott 1977) the content about 1 apfu Ag is typical (Ag occupied a special octahedral position in the crystal structure). The ratio $\mathrm{Fe} /(\mathrm{Ni}+\mathrm{Co})$ is varied in the range $1.34-2.57$ and it contains only traces of Co. Chemical composition of argentopentlandite from Vepice (Tab. 2) fits very well these values: 0.94-0.99 apfu Ag, 4.69-5.08 apfu $\mathrm{Fe}$ and 

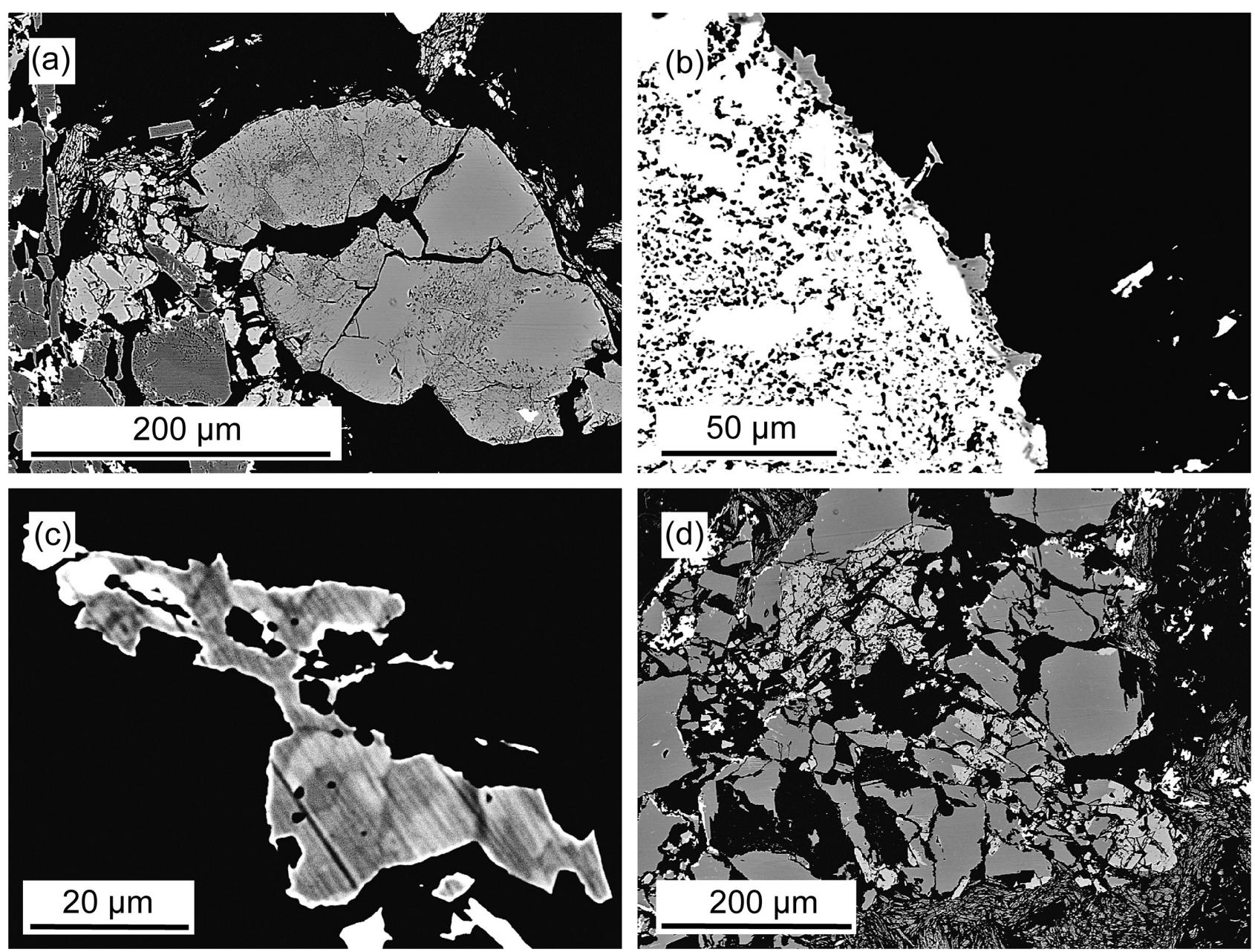

Fig. 4 BSE photographs. a - large lenticular and small tabular crystals of pentlandite (grey) with aggregates of argentopentlandite (light grey), pyrite (dark grey) and galena (white); b - small parkerite aggregates (grey) overgrow galena (white); $\mathbf{c}$ - zonal character of parkerite aggregate; d - chalcopyrite grains (dark grey) with argentopentlandite aggregates (light grey) and numerous subparallel arranged tabular pentlandite crystals (grey) and galena (white).

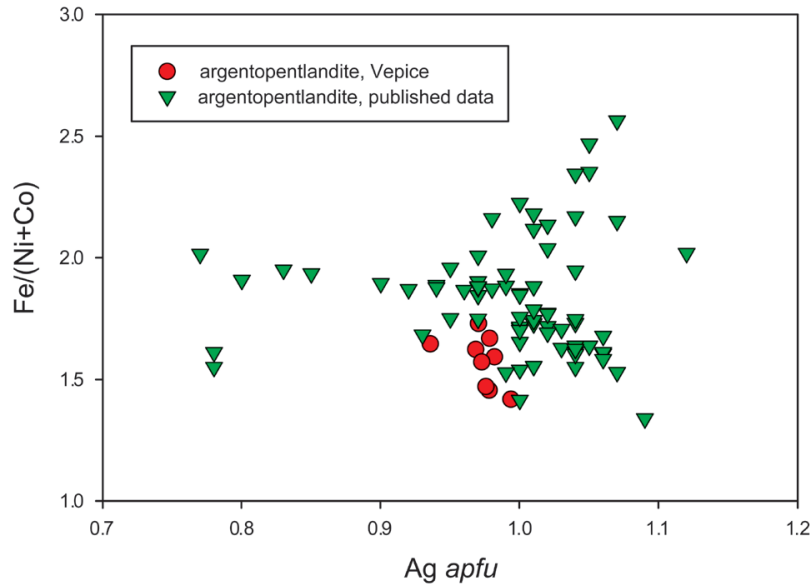

Fig. 5 The Ag contents vs $\mathrm{Fe} /(\mathrm{Ni}+\mathrm{Co})$ ratio for argentopentlandite; published data for argentopentlandite from various localities around the world are taken from Morales-Ruano and Hach-Alí (1996).

2.93-3.29 apfu Ni, Fe/(Ni+Co) $=1.41-1.73$ (Fig. 5) and Co $\leq 0.01 \mathrm{apfu}$. Empirical formula (mean of 8 analyses)

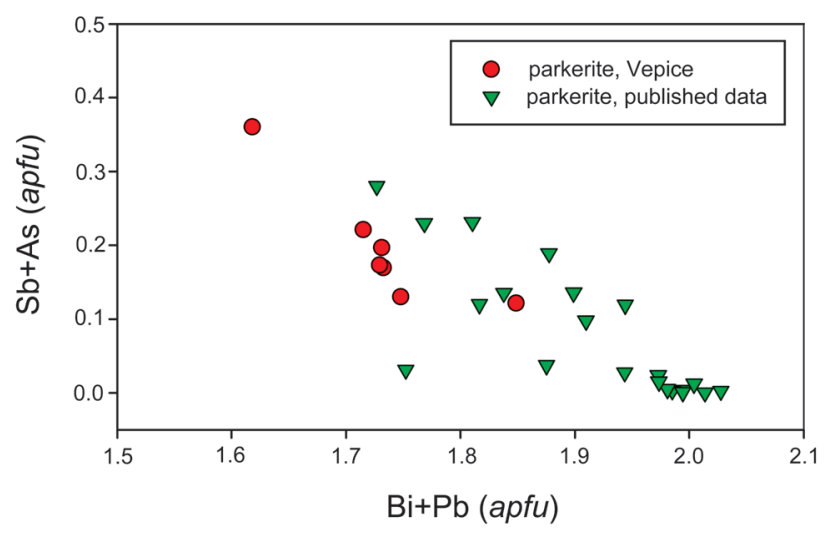

Fig. 6 Graph of $\mathrm{Bi}+\mathrm{Pb} v s$. $\mathrm{Sb}+\mathrm{As}$ contents $(a p f u)$ for parkerite; published data has been taken from Paar and Chen (1979), Ondruš et al. (2003), Goryachev et al. (2004), Rumsey and Savage (2005) and Spiridonov et al. (2007).

normalized on $17 \mathrm{apfu}$ is $\mathrm{Ag}_{0.97}\left(\mathrm{Fe}_{4.88} \mathrm{Ni}_{3.10} \mathrm{Cu}_{0.04} \mathrm{Co}_{0.01}\right)_{\Sigma 8.03}$ $\left(\mathrm{S}_{7.96} \mathrm{As}_{0.03}\right)_{\Sigma 7.99}$ 
Nickel-(Bi,Ag) sulphide mineralization from NYF Vepice pegmatite

Parkerite is less common and its irregular aggregates, 20-30 $\mu \mathrm{m}$ in size, are typically associated with pentlandite; scarcely small aggregates, $10 \mu \mathrm{m}$ in size, overgrow galena (Fig. 4b). Locally, aggregates show in BSE image significant zoning (Fig. 4c) due to $\mathrm{BiSb}_{-1}$ substitution. The ideal chemical formula for parkerite is reported as $\mathrm{Ni}_{3}(\mathrm{Bi}$, $\mathrm{Pb})_{2} \mathrm{~S}_{2}$ (Anthony et al. 1990), due to the existence of limited substitution $\mathrm{BiPb}_{-1}$ in the parkeriteshandite series (Fleet 1973). Occurrences of parkerite with various $\mathrm{Pb}$ contents are described by Petruk et al. (1969), Ondruš et al. (2003) and Fojt et al. (2008), and Spiridonov et al. (2007) found at samples from Norilsk besides $\mathrm{Pb}$-rich parkerite also its metacrysts with negligible $\mathrm{Pb}$ contents. The chemical analyses of $\mathrm{Pb}$-free parkerite were published by Petruk et al. (1969), Groves and Hall (1978) and Sejkora et al. (2009). Chemical composition of parkerite from Vepice and empirical formulae are given in Tab. 3. This mineral is $\mathrm{Pb}$-free but at the $B i$ position of ideal formula (Fig. 6) $\mathrm{Bi}(1.65-1.85$ $a p f u)$ is substituted by $\mathrm{Sb}(0.02-0.27 a p f u)$ and locally also by As (up to $0.10 \mathrm{apfu}$ ). A similar range of $\mathrm{BiSb}_{-1}$ substitution at parkerite is reported by Paar and Chen (1979), Go-

Tab. 3 Chemical composition of parkerite (wt. \%)

\begin{tabular}{lrrrrrrr}
\hline & mean & \multicolumn{1}{c}{2} & \multicolumn{1}{c}{3} & \multicolumn{1}{c}{4} & \multicolumn{1}{c}{5} & \multicolumn{1}{c}{6} \\
\hline $\mathrm{Fe}$ & 0.21 & 0.17 & 0.03 & 0.14 & 0.36 & 0.25 & 0.28 \\
$\mathrm{Ni}$ & 28.21 & 28.68 & 28.13 & 28.58 & 27.65 & 28.50 & 27.70 \\
$\mathrm{Co}$ & 0.03 & 0.03 & 0.00 & 0.03 & 0.04 & 0.03 & 0.05 \\
$\mathrm{Cu}$ & 0.06 & 0.05 & 0.00 & 0.00 & 0.25 & 0.08 & 0.00 \\
$\mathrm{Sb}$ & 2.98 & 5.34 & 3.25 & 3.35 & 2.49 & 3.07 & 0.38 \\
$\mathrm{Bi}$ & 57.50 & 55.05 & 56.98 & 57.31 & 57.46 & 57.52 & 60.66 \\
$\mathrm{As}$ & 0.51 & 1.11 & 0.00 & 0.00 & 0.00 & 0.77 & 1.19 \\
$\mathrm{~S}$ & 10.27 & 10.41 & 10.34 & 10.22 & 10.39 & 10.29 & 10.01 \\
\hline total & 99.77 & 100.85 & 98.73 & 99.63 & 98.63 & 100.52 & 100.27 \\
\hline $\mathrm{Fe}$ & 0.023 & 0.019 & 0.003 & 0.015 & 0.041 & 0.028 & 0.032 \\
$\mathrm{Ni}$ & 3.023 & 3.001 & 3.046 & 3.070 & 2.993 & 3.025 & 3.006 \\
$\mathrm{Co}$ & 0.003 & 0.003 & 0.000 & 0.003 & 0.004 & 0.003 & 0.005 \\
$\mathrm{Cu}$ & 0.006 & 0.005 & 0.000 & 0.000 & 0.025 & 0.008 & 0.000 \\
\hline$\Sigma N i$-site & 3.055 & 3.028 & 3.049 & 3.088 & 3.063 & 3.063 & 3.042 \\
\hline $\mathrm{Sb}$ & 0.154 & 0.269 & 0.170 & 0.174 & 0.130 & 0.157 & 0.020 \\
$\mathrm{Bi}$ & 1.731 & 1.618 & 1.733 & 1.729 & 1.748 & 1.715 & 1.849 \\
$\mathrm{As}$ & 0.043 & 0.091 & 0.000 & 0.000 & 0.000 & 0.064 & 0.102 \\
\hline$\Sigma B i$-site & 1.928 & 1.979 & 1.903 & 1.903 & 1.878 & 1.936 & 1.970 \\
\hline $\mathrm{S}$ & 2.016 & 1.993 & 2.049 & 2.009 & 2.060 & 2.000 & 1.988 \\
\hline $\mathrm{Co}$ & & &
\end{tabular}

Coefficients of empirical formula were calculated on the basis of $7 \mathrm{apfu}$.
Tab. 2 Chemical composition of argentopentlandite (wt. \%)

\begin{tabular}{|c|c|c|c|c|c|c|c|c|c|}
\hline & mean & 1 & 2 & 3 & 4 & 5 & 6 & 7 & 8 \\
\hline $\mathrm{Ag}$ & 12.75 & 12.91 & 12.82 & 12.80 & 12.90 & 12.72 & 12.81 & 12.40 & 12.67 \\
\hline $\mathrm{Fe}$ & 33.14 & 31.53 & 32.22 & 32.25 & 33.17 & 33.57 & 33.85 & 34.11 & 34.39 \\
\hline $\mathrm{Pb}$ & 0.08 & 0.13 & 0.03 & 0.05 & 0.05 & 0.08 & 0.13 & 0.08 & 0.05 \\
\hline $\mathrm{Ni}$ & 22.12 & 23.30 & 23.25 & 23.02 & 21.86 & 21.69 & 21.27 & 21.75 & 20.81 \\
\hline Co & 0.05 & 0.08 & 0.03 & 0.05 & 0.03 & 0.05 & 0.05 & 0.04 & 0.09 \\
\hline $\mathrm{Cu}$ & 0.31 & 0.06 & 0.17 & 0.16 & 0.37 & 0.48 & 0.50 & 0.17 & 0.55 \\
\hline $\mathrm{Sb}$ & 0.06 & 0.15 & 0.20 & 0.00 & 0.00 & 0.00 & 0.00 & 0.00 & 0.14 \\
\hline $\mathrm{Bi}$ & 0.04 & 0.19 & 0.00 & 0.04 & 0.04 & 0.02 & 0.00 & 0.00 & 0.00 \\
\hline As & 0.28 & 0.12 & 0.10 & 0.24 & 0.33 & 0.48 & 0.48 & 0.13 & 0.38 \\
\hline $\mathrm{S}$ & 31.02 & 30.78 & 31.03 & 31.17 & 31.19 & 31.00 & 30.77 & 31.62 & 30.58 \\
\hline total & 99.84 & 99.26 & 99.84 & 99.78 & 99.94 & 100.09 & 99.86 & 100.29 & 99.66 \\
\hline$\overline{\mathrm{Ag}}$ & 0.973 & 0.994 & 0.978 & 0.976 & 0.982 & 0.968 & 0.978 & 0.936 & 0.970 \\
\hline $\mathrm{Fe}$ & 4.882 & 4.688 & 4.748 & 4.749 & 4.879 & 4.935 & 4.997 & 4.973 & 5.086 \\
\hline $\mathrm{Pb}$ & 0.003 & 0.005 & 0.001 & 0.002 & 0.002 & 0.003 & 0.005 & 0.003 & 0.002 \\
\hline $\mathrm{Ni}$ & 3.100 & 3.294 & 3.259 & 3.224 & 3.058 & 3.034 & 2.987 & 3.017 & 2.929 \\
\hline Co & 0.007 & 0.011 & 0.004 & 0.006 & 0.004 & 0.006 & 0.007 & 0.005 & 0.011 \\
\hline $\mathrm{Cu}$ & 0.040 & 0.008 & 0.022 & 0.021 & 0.048 & 0.061 & 0.064 & 0.021 & 0.071 \\
\hline $\mathrm{Sb}$ & 0.004 & 0.010 & 0.013 & 0.000 & 0.000 & 0.000 & 0.000 & 0.000 & 0.009 \\
\hline $\mathrm{Bi}$ & 0.001 & 0.008 & 0.000 & 0.002 & 0.002 & 0.001 & 0.000 & 0.000 & 0.000 \\
\hline As & 0.031 & 0.014 & 0.011 & 0.027 & 0.036 & 0.052 & 0.052 & 0.014 & 0.042 \\
\hline $\mathrm{S}$ & 7.959 & 7.969 & 7.964 & 7.993 & 7.989 & 7.938 & 7.909 & 8.031 & 7.879 \\
\hline
\end{tabular}

ryachev et al. (2004), and Rumsey and Savage (2005). This is interesting because the experimental work of Brower et al. (1974) indicates that a hypothetical Sb end-member with a parkerite-type composition (i.e., $\mathrm{Ni}_{3} \mathrm{Sb}_{2} \mathrm{~S}_{2}$ ) does not exist and that the stable $\mathrm{Ni}-\mathrm{Sb}-\mathrm{S}$ bearing phase is ullmannite (NiSbS). The empirical formula of parkerite (mean of 6 analyses $)$ is $\left(\mathrm{Ni}_{3.02} \mathrm{Fe}_{0.02} \mathrm{Co}_{0.01}\right)_{\Sigma 3.06}\left(\mathrm{Bi}_{1.73} \mathrm{Sb}_{0.05} \mathrm{As}_{0.04}\right)_{\Sigma 1.92}$ $\mathrm{S}_{2.02}$, based on 7 apfu.

Tab. 4 Chemical composition of pentlandite (wt. \%)

\begin{tabular}{lrrrrrr}
\hline & mean & \multicolumn{1}{c}{1} & \multicolumn{1}{c}{2} & \multicolumn{1}{c}{3} & \multicolumn{1}{c}{4} & \multicolumn{1}{c}{5} \\
\hline $\mathrm{Ag}$ & 0.02 & 0.05 & 0.00 & 0.02 & 0.00 & 0.00 \\
$\mathrm{Fe}$ & 29.76 & 28.38 & 28.76 & 28.93 & 31.23 & 31.48 \\
$\mathrm{~Pb}$ & 0.08 & 0.12 & 0.13 & 0.08 & 0.02 & 0.04 \\
$\mathrm{Ni}$ & 34.52 & 37.22 & 35.95 & 35.45 & 31.96 & 32.03 \\
$\mathrm{Co}$ & 2.04 & 1.91 & 2.48 & 2.17 & 1.81 & 1.85 \\
$\mathrm{Cu}$ & 0.02 & 0.02 & 0.04 & 0.05 & 0.00 & 0.00 \\
$\mathrm{Sb}$ & 0.05 & 0.04 & 0.00 & 0.00 & 0.10 & 0.10 \\
$\mathrm{As}$ & 0.19 & 0.11 & 0.00 & 0.30 & 0.04 & 0.51 \\
$\mathrm{~S}$ & 33.07 & 33.41 & 33.69 & 32.23 & 33.08 & 32.96 \\
\hline total & 99.75 & 101.27 & 101.05 & 99.23 & 98.24 & 98.96 \\
\hline $\mathrm{Ag}$ & 0.001 & 0.004 & 0.000 & 0.002 & 0.000 & 0.000 \\
$\mathrm{Fe}$ & 4.139 & 3.896 & 3.947 & 4.065 & 4.391 & 4.408 \\
$\mathrm{~Pb}$ & 0.003 & 0.004 & 0.005 & 0.003 & 0.001 & 0.001 \\
$\mathrm{Ni}$ & 4.568 & 4.860 & 4.692 & 4.738 & 4.274 & 4.266 \\
$\mathrm{Co}$ & 0.250 & 0.230 & 0.299 & 0.268 & 0.224 & 0.227 \\
$\mathrm{Cu}$ & 0.003 & 0.003 & 0.004 & 0.006 & 0.000 & 0.000 \\
$\mathrm{Sb}$ & 0.003 & 0.003 & 0.000 & 0.000 & 0.007 & 0.006 \\
$\mathrm{As}$ & 0.020 & 0.011 & 0.000 & 0.032 & 0.004 & 0.053 \\
$\mathrm{~S}$ & 8.013 & 7.988 & 8.052 & 7.888 & 8.100 & 8.038 \\
\hline $\mathrm{Coch}$
\end{tabular}

Coefficients of empirical formula were calculated on the basis of $17 \mathrm{apfu}$. 
Pentlandite is present in two morphological forms: lenticular to isometric anhedral grains, up to $\sim 200 \mu \mathrm{m}$ in size, are relatively rare (Fig. 4a) whereas numerous small tabular crystals, up to $20 \mu \mathrm{m}$ in length, are in subparallel arrangement rimming aggregates of other sulphides (Fig. 2b, 4a, 4d). The chemical composition (Tab. 4) is characterized by predominance of $\mathrm{Ni}(4.27-4.86 \mathrm{apfu})$ over Fe (3.90-4.41 apfu) with only limited Co contents (0.23-0.30 apfu). In contrast to the argentopentlandite present in this association, pentlandite shows only irregular and very low Ag contents $\leq 0.003$ apfu. With $\mathrm{Fe} / \mathrm{Ni}$ ratios between $0.80-1.03$ and metal/sulphur ratio $1.10-1.13$ close to the theoretical value of 1.125 , this is the usual chemical composition of pentlandite (Rajamani and Prewitt 1973). The empirical formula of pentlandite (mean of 5 analyses) is possible to express on the basis of 17 apfu as $\left(\mathrm{Ni}_{4.57} \mathrm{Fe}_{4.14} \mathrm{Co}_{0.25}\right)_{\Sigma 8.96}$ $\left(\mathrm{S}_{8.01} \mathrm{As}_{0.02}\right)_{\Sigma 8.03}$.

\section{Discussion}

\subsection{Comparison of the Vepice pegmatites with NYF pegmatites from other Moldanubian durbachite plutons}

Intragranitic NYF pegmatites typically occur in some Variscan durbachite plutons (amphibole-biotite melagranite to melasyenite) of the Moldanubian Zone; they are common and studied in detail at numerous localities within the Třebíč Pluton (e.g., Čech 1957; Staněk 1973; Škoda et al. 2006; Škoda and Novák 2007; Novák and Filip 2010; Novák et al. 2011; Čopjaková et al. 2013; Výravský et al. 2017; Zachař et al. 2020), they are common in the Kovářov vicinity at the Milevsko Pluton (Škoda et al. 2004; Novák 2005), and rare in the Mehelník Pluton near Písek (Novák et al. 2017). The granitic pegmatites from Vepice near Kovářov are similar to NYF pegmatites from the Třebíč Pluton. They show comparable internal structure only the pegmatite No. I (and some other dikes in the Kovářov region) differs in the presence of large central pocket (m-sized) whereas pockets in pegmatites of the Třebíc Pluton are rare and small (centimeter-sized). The mineral assemblages with typical minor and accessory minerals - phlogopite, tourmaline, titanite, ilmenite and absence of primary muscovite are very similar as well. Also the chemical composition of tourmaline (Ca,Ti-rich Al-poor schorl-dravite) from the dike No. III is comparable with tourmalines from the Třebíč Pluton (Novák et al. 2011; Čopjaková et al. 2013). However, Y, REE-minerals (samarskite-, pyrochlore-, aeschynite- and euxenite-group) and allanite are less common and present mainly in the pegmatite No. I. Also rather common sulphides (pyrite, galena, and chalcopyrite) as well as mi- croscopic Ni-(Bi, Ag) sulphides are distinct. In the Třebíč Pluton, only pyrite along with less common arsenopyrite are rather common sulphides whereas carbonates and fluorite have not been found (Škoda et al. 2006; Zachař et al. 2020). Disregarding some differences, the internal structure and mineral assemblages of the pegmatites in Vepice and other localities of the Milevsko Pluton are very similar to other NYF pegmatites from durbachite plutons (Třebíč, Mehelník) and suggest euxenite-type (Černý and Ercit 2005) for the pegmatite No. I and pegmatite No. II, although Škoda et al. (2004) suggested more evolved gadolinite type, in the sense of Černý and Ercit (2005), for No. I pegmatite. Less evolved pegmatite No. III likely belongs to allanite-type. Occurrence of calcite and fluorite in some dikes is distinct from the pegmatites in Třebíč Pluton but presence of fluorite fits very well with the NYF signature of the pegmatites (Černý and Ercit 2005; Simmons and Weber 2008).

\subsection{Paragenetic sequence of sulphide minerals}

Evaluation of relative chronology of the present sulphide minerals is complicated due to these facts: (i) ore minerals often form individual grains or aggregates separated from neighbouring ones by non-ore phases (silicates, calcite, fluorite); (ii) isolated domains with contrasting mineral compositions typically contain an only restricted number of ore minerals; (iii) crosscutting phenomena are very rare in the studied material. In addition, simple chemistry of some phases occurring in various textural developments also precludes checking for the possible presence of multiple generations of certain phases (i.e., galena or pentlandite).

The textural criteria suggest that the oldest objects in the studied ore assemblage probably are aggregates now-formed by pyrite and marcasite, which are rimmed by grains of most other sulphides (chalcopyrite, argentopentlandite, galena, pentlandite; Figs 2d, 4a). The nature of pyrite-marcasite aggregates suggests that they likely represent pseudomorphs after pyrrhotite (Murowchick 1992). Transformation of pyrrhotite into iron disulphides occurred after crystallization of chalcopyrite as is supported by the occurrence of a veinlet of both Fe-sulphides cutting chalcopyrite and prior formation of galena which overgrows grains of Fe-sulphides. Younger phases with respect to original pyrrhotite are sphalerite, chalcopyrite and argentopentlandite. These minerals occur in close spatial association or even in intimate intergrowths indicating contemporaneous crystallization. Galena followed them in the paragenetic sequence, as it often grows over their aggregates (Figs 2a, 2b). Rounded inclusions of native bismuth randomly enclosed in galena are contemporaneous. In contrast, another type of native bismuth, forming evident veinlets in galena, is younger. Origin of intimate intergrowths of fine-grained bismuth and galena occurring 
in sharply restricted small areas hosted by pure galena void of bismuth inclusions remains unresolved. Morphological and textural features suggest that these objects could represent breakdown products after an unstable mineral, but no relics of such a phase were observed. Parkerite is clearly younger than galena (Fig. 4b), but its relation to native bismuth is not clear because of the lack of direct contact. Among the youngest phases present there are fine-grained tabular pentlandite, whose "fluidal" aggregates run-around grains/aggregates of all earlier phases including parkerite and galena (Figs 2b, 4a, 4d).

\subsection{Conditions of origin of sulphide mineralization}

Sulphides and sulphosalts are among the less studied minerals in granitic pegmatites (London 2008) although sulphide mineralizations are highly variable in textures and chemical composition (e.g., Oen and Kieft 1976; Černý and Harris 1978; Kissin et al. 1978; Losos et al. 1998; Černý et al. 2001; Škoda and Čopjaková 2005; Kozłowski and Sachanbiński 2007; Márquez-Zavalía et al. 2012) and very likely in their origin as well. Some sulphides form euhedral to subhedral crystals mostly enclosed in quartz. They may be considered as primary magmatic by origin, such as bismuthinite from the NYF La Elsa pegmatite, Argentina (Škoda et al. 2020), molybdenite crystals from the pegmatite Lipovy Log, Ural Mts. (Mao et al. 2003) and assemblage pyrite, pyrrhotite, chalcopyrite, bornite and molybdenite from primitive anatectic pegmatites at Nagamalai-Pudukottai area, Tamil Nadu, India (Raj and Kumar 2015). Mostly fine-grained aggregates of a single mineral or mixture of several sulphides, sulphosalts and/or native metals and their alloys $(\mathrm{Cu}, \mathrm{Pb}, \mathrm{Zn}, \mathrm{Cd}, \mathrm{Bi}, \mathrm{Ag}, \mathrm{Sb}, \mathrm{As}$, $\mathrm{Te})$ are subsolidus in origin. Anhedral to subhedral grains, and aggregates of rather common native bismuth with the melting point about $260-270^{\circ} \mathrm{C}$ (e.g., Živkovič and Živkovič 1996; Valladares et al. 2018) is mostly among the earliest phases in these assemblages, and it suggests that sulphides crystallized at evidently lower $\mathrm{T}$ typically $\sim 200-100^{\circ} \mathrm{C}$ (e.g., Černý and Harris 1978; Márquez-Zavalía et al. 2012). In contrast, crystallization of stannitegroup minerals, typical sulphides in granitic pegmatites (Kissin et al. 1978; Černý et al. 2001), proceeded at higher $\mathrm{T} \sim 400^{\circ} \mathrm{C}$. Even higher $\mathrm{T}=550-370^{\circ} \mathrm{C}$ is suggested by Losos et al. (1998) for the assemblage stannite-gustavitelilianite-Ag-rich galena with $\mathrm{Bi}$ inclusions, whereas the assemblage siderite-hedleyite-native Bi-hessite crystallized at $\mathrm{T}<270^{\circ} \mathrm{C}$ in pegmatites of the Žulová pluton. High T, up to $\sim 500^{\circ} \mathrm{C}$, is also supposed for the early assemblage wittichenite-chalcopyrite-bornite from beryl-columbitephosphate pegmatite at Mangualde, Portugal (Oen and Kieft 1976), whereas late minerals in this assemblage such as emplectite, matildite, Ag-bearing Bi-rich tennantite and tetrahedrite were formed at $\mathrm{T} \sim 200^{\circ} \mathrm{C}$ by the reaction of exsolved wittichenite with native bismuth, arsenopyrite, and löllingite.

The examined Ni-( $\mathrm{Bi}, \mathrm{Ag})$ sulphide mineralization is negligible in volume and is associated with dominant pyrite and minor galena, chalcopyrite, rare sphalerite and bismuth. Argentopentlandite, pentlandite and parkerite occur only on a microscopic scale as irregular aggregates and inclusions in major and minor sulphides. The temperature of the crystallization of sulphides is constrained by the textural relations and mineral assemblage: polysynthetic twinning of chalcopyrite suggests the transformation of high-temperature cubic chalcopyrite to tetragonal one at $\mathrm{T}=550{ }^{\circ} \mathrm{C}$ (Kostov and Stefanova 1981; Čvileva et al. 1988); sphalerite stars in chalcopyrite indicate $\mathrm{T} \sim 500-400^{\circ} \mathrm{C}$ (Kostov and Stefanova 1981; Sugaki et al. 1987), argentopentlandite has the upper limit of $\mathrm{T}<455^{\circ} \mathrm{C}$ (Mandziuk and Scott 1977), marcasite has the upper-temperature stability limit at $\mathrm{T}=\sim 240^{\circ} \mathrm{C}$ (Murowchick 1992), and native bismuth as the late mineral suggests $\mathrm{T}<\sim 270^{\circ} \mathrm{C}$ (melting point $271^{\circ} \mathrm{C}$, Živkovič and Živkovič $1996 ; \mathrm{T}=267$ to $250^{\circ} \mathrm{C}$ at $\mathrm{P}=1$ to $5 \mathrm{kbar}$, Valladares et al. 2018). Early sulphides (pyrrhotite, chalcopyrite, sphalerite, argentopentlandite) crystallized at $\mathrm{T}<\sim 400-450{ }^{\circ} \mathrm{C}$, whereas pyrite, marcasite, galena, parkerite, and native $\mathrm{Bi}$ at $\mathrm{T}<240^{\circ} \mathrm{C}$. Because of low stability of marcasite, which is at high temperatures rapidly transformed to pyrite (Murowchick 1992), we can assume cooling of the system below $\mathrm{T} \sim 200^{\circ} \mathrm{C}$ soon after transformation of pyrrhotite to pyrite + marcasite aggregates.

The temperature of crystallization of sulphides, sulphosalts and native bismuth at Vepice varying from $\mathrm{T} \sim 450-400{ }^{\circ} \mathrm{C}$ to $\mathrm{T}<\sim 240{ }^{\circ} \mathrm{C}$ is much higher than complex assemblages including from Li-pegmatites Tanco, Manitoba, Canada (Černý and Harris 1978) and El Quemado pegmatite, Nevados de Palermo, Argentina (Márquez-Zavalía et al. 2012) where $\mathrm{T} \sim 200-100^{\circ} \mathrm{C}$ is suggested. However, the estimated high-T limit of the sulphide crystallization for Vepice is close to kesteritestannite from quartz core at the spodumene subtype pegmatite Peerless, Black Hills, S. Dakota (Černý et al. 2001) and the assemblage wittichenite-chalcopyritebornite from the beryl-columbite-phosphate subtype pegmatite at Mangualde, Portugal (Oen and Kieft 1976) and the assemblage stannite-gustavite-lilianite-Ag-rich galena with $\mathrm{Bi}$ inclusions at the pegmatites of the Žulová Pluton (Losos et al. 1998).

\subsection{Source of Ni and Ag and potential geological implications}

Geological setting and chemical composition of parental granites, including concentrations of trace elements is 
a crucial factor for the chemical composition of minerals in granitic pegmatites (e.g., London 2008; Černý et al. 2012). Novák et al. (2012) manifested that elevated trace concentrations of Cs (20-40 ppm) and Sc (12-27) in the parental granite (durbachite) are reflected in the composition of accessory minerals in the pegmatites of the Třebíc Pluton. Disregarding the fact that Cs is highly incompatible and Sc highly compatible element, Cs, Sc-enriched beryl + secondary bazzite (Novák and Filip 2010) and Sc-enriched columbite (Novák and Čech 1996; Novák and Černý 1998; Výravský et al. 2017) and its breakdown products including kristiansenite, thortveitite and $\mathrm{ScNbO}_{4}$ phase (Výravský et al. 2017) were found in these pegmatites.

Durbachites display a rather unusual mineral and chemical compositions comparing ordinary parental granite plutons of granitic pegmatites (e.g., Linnen and Cuney 2005; Ercit 2005; Černý et al. 2005); consequently, we can expect some specific minerals or mineral compositions in the relevant granitic pegmatites. Durbachites are rich in $\mathrm{Ni}$ (59-235 ppm); however, geochemical fractionation separates compatible and incompatible elements; hence, highly compatible Ni can hardly be expected in minerals from fractionated granitic pegmatites. Moreover, FM-minerals such as phlogopite, actinolite and tourmaline (tourmaline - 356 to $1186 \mathrm{ppm} \mathrm{Ni}$; Novák et al. 2011; Čopjaková et al. 2013) are common. They crystallized in outer textural-paragenetic units of these pegmatites and may have incorporated Ni into crystal structures and thus exhaust Ni from the melt. Surprisingly, Ni-rich sulphides from the No. III pegmatite in Vepice manifest that concentrations of $\mathrm{Ni}$ in residual pegmatite melt and exsolved fluids were rather high and facilitated its saturation in sulphides, although only in a microscopic amount. Nevertheless, tourmaline as an essential carrier of $\mathrm{Ni}$ in pegmatites is very rare in No. III pegmatite. A very high $\mathrm{Ni} / \mathrm{Co}$ ratio in sulphides reflects a much lower concentration of Co in durbachite (14-28 $\mathrm{ppm})$ relative to $\mathrm{Ni}$.

Silver-bearing sulphides and sulphosalts are known only from Tanco, Manitoba (Černý and Harris 1978) and pegmatites from the Žulová Pluton (Losos et al. 1998). Concentrations of $\mathrm{Ag}$ in durbachites are mostly below 1 ppm (Janoušek et al. 2020), but Ag was measured in granites only very sporadically. Nevertheless, such a low concentration in parental granite may be sufficient for the origin of Ag-rich mineral in a product of geochemical fractionation - granitic pegmatite, although argentopentlandite is a very rare accessory mineral. The source of $\mathrm{S}$, As and metals $(\mathrm{Fe}, \mathrm{Pb}, \mathrm{Cu}, \mathrm{Zn}, \mathrm{Bi})$ is considered the residual pegmatite melt and its exsolved fluids. Contamination from fluids derived in host durbachite is possible, e.g., the substitution of pyrrhotite by pyrite (marcasite) requires an evident increase of redox potential (Murowchick 1992).

\section{Conclusion}

Chemical composition of granites, including concentrations of trace elements is a crucial factor for the chemical composition of minerals in related granitic pegmatites (e.g., London 2008; Černý et al. 2012). The examined $\mathrm{Ni}-(\mathrm{Bi}, \mathrm{Ag})$ sulphides from intragranitic pegmatite No. III at Vepice, although present only in microscopic scale, manifest that high concentrations of highly compatible Ni in granite may be reflected in accessory minerals similarly as in the case of Cs and Sc in the Třebíc Pluton (Novák and Filip 2010). Consequently, accessory minerals in granitic pegmatites may serve as fingerprints of trace element composition of their potential parental granites; however, a much larger dataset from granites and related pegmatites is necessary to collect in order to confirm this idea.

Acknowledgements. The authors thank Daniel Ozdín (Comenius University, Faculty of Science, Bratislava) for his kind help with the analytical work. The reviewers, Anna Vymazalová and Zdeněk Losos, same as handling Editor Jiř́ Zachariáš and the Editor-in-Chief Jakub Plášil, are thanked for a lot of their constructive comments. This work was supported financially by the Ministry of Culture of the Czech Republic (long-term project DKRVO 2019-2023/1.I.b National Museum, 00023272) and the Research project of Masaryk University MUNI/A/1479/2019 (for MN).

\section{References}

Anthony JW, Bideaux RA, Bladh KW, Nichols MC (1990) Handbook of Mineralogy. Volume I. Elements, Sulfides, Sulfosalts. Mineral Data Publishing, Tucson, pp 1-588

Breiter K, Cempírek J, Kadlec T, Novák M, ŠKoda R (2010) Granitic pegmatites and mineralogical museums in Czech Republic. Acta Mineral Petrogr, IMA 2010 Field Guide Series, 6: 1-56

Brower WS, PArker HS, Roth RS (1974) Reexamination of synthetic parkerite and shandite. Amer Miner 59: 296-301

ČECH F (1957) Priorite (blomstrandine) from Pozd’átky near Třebíč. Čas Mineral Geol 2: 346-348 (in Czech)

ČERNÝ P, ERCIT TS (2005) The classification of granitic pegmatites revisited. Canad Mineral 43: 2005-2026

ČERNÝ P, HARRIS DC (1978) The Tanco pegmatite at Bernic Lake, Manitoba; XI, Native elements, alloys, sulfides and sulfosalts. Canad Mineral 16(4): 625-640

Černý P, Massau M, Ercit TS, Chapman R, ChackowsKi LE (2001) Stannite and kesterite from the Peerless pegmatite, Black Hills, South Dakota, USA. J Geosci 46(1-2): 27-34 
ČERnÝ P, BleVin PL, Cuney M, London D (2005) Graniterelated ore deposits. Econ Geol $100^{\text {th }}$ Anniversary Volume, 337-370

ČERNÝ P, LONDON D, NovÁK M (2012) Granitic pegmatites as reflection of their sources. Elements 8: 289-294

Chvileva TN, Bezsmertnaya MS, Spiridonov EM, Agroskin as, Papayan GV, Vinogradova RA, Lebedeva Si, Zavyalov EN, Filimonova AA, Petrov VK, Rautian LI, Svesnikova OL (1988) Handbook for determination of ore minerals in reflected light. Moskva, pp 1-504 (in Russian)

Ciobanu CL, Cook NJ (2002) Comparison of primary bismuth association in two southern African pegmatites. In Proc. 11th Quadrennial IAGOD Symp. and Geocongress (Windhoek), CD Extended Abstracts (CD-ROM), Geol Surv Namibia

Čopjaková R, ŠKoda R, VašInoví-Galiová M, Novák M (2013) Distributions of Y + REE and Sc in tourmaline and their implications for the melt evolution; examples from NYF pegmatites of the Třebič Pluton, Moldanubian Zone, Czech Republic. J Geosci 58: 113-131

Čopjaková R, ŠKoda R, Vašinová-Galiová M, Novák M, CEMPÍReK J (2015) Scandium- and REE-rich tourmaline replaced by Sc-rich REE-bearing epidote-group mineral from the mixed (NYF + LCT) Kracovice pegmatite (Moldanubian Zone, Czech Republic). Amer Miner 100: 1434-1451

ERCIT TS (2005) REE-enriched granitic pegmatites. Rareelement geochemistry and mineral deposits: Geological Association of Canada, GAC Short Course Notes 17: 175-199

Finger F, Roberts MP, Haunschmid B, Schermaier A, STEYRER HP (1997) Variscan granitoids of central Europe: their typology, potential sources and tectonothermal relations. Mineral Petrol 61: 67-96

FLEET ME (1973) The crystal structure of parkerite $\left(\mathrm{Ni}_{3} \mathrm{Bi}_{2} \mathrm{~S}_{2}\right)$. Amer Miner 58: 435-439

Fojt B, Dobeš P, Malý K, ŠKoda R (2008) Ore minerals from the dolomitic veins in the serpentine rocks of the Letovice crystalline complex (Czech Republic). Acta Mus Moraviae, Sci geol 93: 3-18 (in Czech)

Fuksoví A, DolníčeK Z, Gadas P (2011) Mineralogy of sulphide, arzenide and telluride mineralization in cordierite-bearing pegmatite from the Bory Quarry near Velké Meziř́čí (Strážek Moldanubicum). Geol výzk Mor Slez 125-127 (in Czech)

Goryachev NA, Gamyanin GN, Zayakina NV, Popova SK, Sidorov VA (2004) The first find of Sb-parkerite in the Russian Northeast. Dokl Russ Acad Sci, Earth Sci Sec 399A: 1260-1263 (in Russian)

Groves DI, HaLl SR (1978) Argentian pentlandite with parkerite, joseite $\mathrm{A}$ and the probable $\mathrm{Bi}$-analogue of ullmannite from Mount Windarra, Western Australia. Canad Mineral 16: 1-7
HaLl SR, Stewart JM (1973) The crystal structure of argentian pentlandite $(\mathrm{Fe}, \mathrm{Ni})_{8} \mathrm{AgS}_{8}$, compared ewith the refined structure of pentlandite $(\mathrm{Fe}, \mathrm{Ni})_{9} \mathrm{~S}_{8}$. Canad Mineral 12: 169-177

HARRIS DC, CABri LJ, NobiLING R (1984) Silver-bearing chalcopyrite, a principal source of silver in the Izok Lake massive-sulfide deposit: confirmation by electron- and proton-microprobe analyses. Canad Mineral 22: 493-498

HoLUB FV (1997) Ultrapotassic plutonic rocks of the durbachite series in the Bohemian massif: Petrology, geochemistry and petrogenetic interpretation. Sbor Geol Věd, $\breve{R}$ Geol 31: 5-26

JANOUŠEK V, HoLUB FV (2007) The causal link between HP-HT metamorphism and ultrapotassic magmatism in collisional orogens: case study from the Moldanubian Zone of the Bohemian Massif. Proc Geol Assoc 118: $75-86$

Janoušek V, Holub FV, Verner K, Čopjaková R, Gerdes A, Hora JM, KoŠLER J, TYrRell S (2019) Two-pyroxene syenitoids from the Moldanubian Zone of the Bohemian Massif: Peculiar magmas derived from a strongly enriched lithospheric mantle source. Lithos 342-343: 239-262

Janoušek V, Hanžl P, SvoJTKa M, Hora J, Kochergina Y, Gadas P, Holub FV, Gerdes A, Verner K, HrdLIČKOVÁ K, DALY S, BURIÁNEK D (2020) Ultrapotassic magmatism at the hay day of the Variscan Orogeny - the story of the Třebíč Pluton, the largest durbachitic body in the Bohemian Massif. Int J Earth Sci 109: 1767-1810

Johan Z, Strnad L, Johan V (2012) Evolution of the Cínovec (Zinnwald) granite cupola, Czech Republic: composition of feldspars and micas, a clue to the origin of W, Sn mineralization. Canad Mineral 50(4): 1131-1148

Kissin SA, Owens DR, Roberts WL (1978) Cernyite, a copper-cadmium-tin sulfide with the stannite structure. Canad Mineral 16(2): 139-146

Kostov I, Stefanova JM (1981) Sulphide minerals. Crystal chemistry, parageneses and systematics. Bulgarian Acad Sci, Sofia, pp 1-212

KozŁowski A, SACHANBIŃSKi M (2007). Karkonosze intragranitic pegmatites and their minerals. Granitoids in Poland, AM Monograph 1: 155-178

Leichmann J, Gnojek I, Novák M, Sedlák J, Houzar S (2017) Durbachites from the Eastern Moldanubicum (Bohemian Massif): erosional relics of large, flat tabular intrusions of ultrapotassic melts-geophysical and petrological record. Int J Earth Sci 106: 59-77

LiNNEN RL, CUNEY M (2005) Granite-related Rare-element Deposits and Experimental Constraints on Ta-Nb-W-SnZr-Hf Mineralization. Rare-element Geochemistry and Mineral Deposits. Geological Association of Canada, GAC Short Course Notes 17: 45-68

London D (2008) Pegmatites. Canadian Mineralogist, Special Publication 10: 1-347 
Losos Z, SulovskÝ P, VÁVRA V (1998) Sn-, Bi- a Ag- minerals from pegmatites, aplites and quartz veins of Žulová granitic massif(Silesicum, Czech Republic). Krystalinikum, 24: 53-72

MandZIUK ZL, Scott SD (1977) Synthesis, stability, and phase relations of argentian pentlandite in the system Ag-Fe-Ni-S. Canad Mineral 15: 349-364

Mao J, Du A, Seltmann R, Yu J (2003) Re-Os ages for the Shameika porphyry Mo deposit and the Lipovy Log rare metal pegmatite, central Urals, Russia. Miner Depos 38(2): 251-257

Márquez-ZaValía MF, Galliski MÁ, Černý P, Chapman R (2012) An assemblage of bismuth-rich, tellurium-bearing minerals in the El Quemado granitic pegmatite, Nevados de Palermo, Salta, Argentina. Canad Mineral 50(6): 1489-1498

Martin RF, De Vito C (2005) The patterns of enrichment in felsic pegmatites ultimately depend on tectonic setting. Canad Mineral 43(6): 2027-2048

Morales-Ruano S, Hach-Alí PF (1996) Hydrothermal argentopentlandite at El Charcón, southwestern Spain: mineral chemistry and conditions of formation. Canad Mineral 34: 939-947

MurOWCHICK JB (1992) Marcasite inversion and the petrographic determination of pyrite ancestry. Econ Geol 87: 1141-1152

NovÁk M (2005) Granitic pegmatites of the Bohemian Massif (Czech Republic); mineralogical, geochemical and regional classification and geological significance. Acta Mus Moraviae, Sci Geol 90: 3-74 (in Czech)

NováK M, ČECH F (1996) Scandian columbite and niobian rutile from pegmatites penetrating the Třebíč durbachite massif, western Moravia, Czech Republic. Acta Mus Moraviae, Sci nat 80: 3-8

NovÁK M, ČERNÝ P (1998) Scandium in columbite-group minerals from LCT pegmatites in the Moldanubicum, Czech Republic. Krystalinikum 24(1): 73-89

NovÁK M, FILIP J (2010) Unusual (Na,Mg)-enriched beryl and its breakdown products (beryl II, bazzite, bavenite) from euxenite-type NYF pegmatite related to the orogenic ultrapotassic Třebíc Pluton, Czech Republic. Canad Mineral 48: 615-628

NOVÁK M, ČERNÝ P, SELWAY JB (1999) The zinnwalditemasutomilite-elbaite pegmatite at Kracovice from the Třebíč durbachite massif - a complex pegmatite related to the NYF family. The Eugene E. Foord Memorial Symposium on NYF-type Pegmatites, Denver, Colorado. Canad Mineral 37: 815-816

NovÁk M, ŠKoda R, FiliP J, MaceK I, VAculovič T (2011) Compositional trends in tourmaline from intragranitic NYF pegmatites of the Třebíč Pluton, Czech Republic: an electron microprobe, Mössbauer and LA-ICP-MS study. Canad Mineral 49: 359-380

Novák M, ŠKoda R, Gadas, P, KrmíčeK, L, Č́ernÝ, P
(2012) Contrasting origins of the mixed (NYF+ LCT) signature in granitic pegmatites, with examples from the Moldanubian Zone, Czech Republic. Canad Mineral 50: 1077-1094

Novák M, Cícha J, Čopjaková R, Š́oda R, Galiová MV (2017) Milarite-group minerals from the NYF pegmatite Velká skála, Písek district, Czech Republic: sole carriers of Be from the magmatic to hydrothermal stage. Eur J Mineral 29(4): 755-766

Oen IS, Kieft C (1976) Silver-bearing wittichenite-chalcopyrite-bornite intergrowths and associated minerals in the Mangualde pegmatite, Portugal. Canad Mineral 14(2): 185-193

OndRuš P, Veselovský F, Gabašová A, Hloušek J, Šrein V, Vavř́i I, Skála R, SejKora J, DrábeK M (2003) Primary minerals of the Jáchymov ore district. J Czech Geol Soc 48: 19-147

PaAr WH, Chen TT (1979) Gersdorffit (in zwei Strukturvarietäten) und $\mathrm{Sb}$-hältiger Parkerit, $\mathrm{Ni}_{3}(\mathrm{Bi}, \mathrm{Sb})_{2} \mathrm{~S}_{2}$, von der Zinkwand, Schladminger Tauern, Österreich. Mineral Petrol 26(1-2): 59-67

Petruk W, Harris DC, Stewart JM (1969) Langisite, a new mineral, and the rare minerals cobalt pentlandite, siegenite, parkerite and bravoite from the Langis Mine, Cobalt-vowganda area, Ontario. Canad Mineral 9: 597-616

PieczKa A, GolęBIowska B (2012) Cuprobismutite homologues in granitic pegmatites from Szklarska Poręba, Karkonosze massif, southwestern Poland. Canad Mineral 50(2): 313-324

Pouchou JL, PichoIR F (1985) „PAP“ ( $\varphi \rho Z)$ procedure for improved quantitative microanalysis. In: ARMSTRONG JT (ed) Microbeam Analysis, San Francisco Press 104-106

RAJ RM, Kumar SN (2015) Characterisation of selected sulphides associated with the granitic pegmatites of Nagamalai-Pudukottai area, Madsurai District, Tamil Nadu, India. J Appl Geochem 17(4): 444-450

Rajamani V, Prewitt CT (1973) Crystal chemistry of natural pentlandites. Canad Mineral 12: 178-187

Rumsey M, Savage M (2005) The first British occurrence of parkerite at North Devon United mine, Peter Tavy, Devon. UK J Mines Minerals 25: 19-22

SejKora J, Litochleb J, SüsSer C (2009) The occurrence of parkerite at the uranium ore district Horní Slavkov (Czech Republic). Bull mineral-petrolog Odd Nár Muz (Praha) 17(1): 29-32 (in Czech)

Simmons WB, Webber KL (2008) Pegmatite genesis: state of the art. Eur J Mineral 20: 421-438

ŠKoDA R, ČOPJAKOvÁ R (2005) Unusual Sn mineralization from the NYF pegmatite near Klučov, Třebič Pluton, Moldanubicum. Geol Výzk Mor Slez v r. 2004, 93-97 (in Czech)

ŠKoda R, Novák M (2007) Y,REE,Nb,Ta,Ti-oxide $\left(\mathrm{AB}_{2} \mathrm{O}_{6}\right)$ minerals from REL-REE euxenite-subtype pegmatites 
of the Třebíč Pluton, Czech Republic; substitutions and fractionation trends. Lithos 95: 43-57

ŠKoda R, Novák M, ČERnÝ P, ČERnÝ P (2004) Complex $\mathrm{Nb}$-Ta-Ti oxides from pegmatite in Vepice near Milevsko, Čertovo břemeno massif. Bull mineral-petrolog Odd Nár Muz (Praha) 12: 182-185 (in Czech)

ŠKoda R, Novák M, Houzar S (2006) Granitic NYF pegmatites of the Třebíc Pluton. Acta Mus Moraviae, Sci Geol, 91: 129-176 (In Czech)

ŠKoda R, NovÁK M, MáRQUEZ-ZaVALÍA MF, GALLISKI MÁ, SeJKora J, Čopjakoví R (2020): Bismuth minerals from intragranitic NYF pegmatite La Elsa, Potrerillos granite, Argentina; monitors of fluid evolution from magmatic to hydrothermal stage. Canad Mineral under peer-review

Smeds SA (1993) Herzenbergite (SnS) in Proterozoic granite pegmatites in north-central Sweden. Mineral Mag 57(388): 489-494

Soares DR, Beurlen H, de Brito Barreto S, Da Silva MRR, FERREIRA ACM (2008) Compositional variation of tourmaline-group minerals in the Borborema Pegmatite Province, northeastern Brazil. Canad Mineral 46(5): 1097-1116

Spiridonov EM, Gritsenko JD, Ponomarenko AI (2007) Metamorphogenic-hydrothermal parkerite and associating minerals in Norilsk ore field. Zapisky RMO 136: 39-49 (in Russian)

STANĚK J (1973) Phenakite from Třebíč, Czechoslovakia. Čas Morav muz, Vědy př́r 58: 49-52

Sugaki A, KitaKaze A, KoJIma S (1987) Bulk compositions of intimate intergrowths of chalcopyrite and sphalerite and their genetic implications. Miner Depos 22(1): 26-32

Valladares AA, Rodríguez I, Hinojosa-Romero D, VALLadares A, Valladares RM (2018) Possible superconductivity in the Bismuth IV solid phase under pressure. Sci Rep 8(1): 5946

VÝRAVSKÝ J, ŠKoda R, NováK M (2017) Kristiansenite, thortveitite and $\mathrm{ScNbO}_{4}$ : Products of Ca metasomatism of Sc-enriched columbite-(Mn) from NYF pegmatite Kožichovice II, Czech Republic. NGF Abstracts and Proceedings, No. 2, 169-172

ZACHA ̌̌ A, NovÁK M (2013) Granitic NYF pegmatites in the Velké Meziříčí region, Třebíč Pluton, western Moravia (Czech Republic). Acta Mus Moraviae, Sci Geol 98: 83-100 (In Czech)

ZACHǍ̌ A, NovÁK M, ŠKoda R (2020) Beryllium minerals as monitors of geochemical evolution from magmatic to hydrothermal stage; an example from NYF pegmatites of the Třebíč Pluton, Czech Republic. J Geosci 65: 153-172

ŽÁ́ J, Holub FV, Verner K (2005) Tectonic evolution of a continental magmatic arc from transpression in the upper crust to exhumation of mid-crustal orogenic root recorded by episodically emplaced plutons: the Central Bohemian Plutonic Complex (Bohemian Massif). Int J Earth Sci 94: 385-400

Žıvкovıč Ž, Žıvkovič D (1996) Comparative determination of the infinite dilution constants and interaction parameters in the binary system Bi-Sb. Rud-Metalur Zbor 43(3-4): 215-218 
